\title{
Academic Achievement and Perception of Two Teaching Methods in Histology: Light and Digital Microscopy. Pilot Study
}

\author{
Rendimiento Académico y Percepción de dos Métodos de Enseñanza en Histología: \\ Microscopio de Luz y Microscopio Digital. Estudio Piloto \\ Becerra Daniela $^{1}$; Grob Melisa ${ }^{1}$; Assadi José Luis' ${ }^{2}$; Astorga Cristian ${ }^{1}$; \\ Tricio Jorge ${ }^{3}$; Melelli Rosario ${ }^{2}$; Silva Camila² \& Sabag Natividad ${ }^{1}$
}

BECERRA, D.; GROB, M.; ASSADI, J. L.; ASTORGA, C.; TRICIO, J.; MELELLI, R.; SILVA, C. \& SABAG, N. Academic achievement and perception of two teaching methods in histology: Light and digital microscopy. Pilot study. Int. J. Morphol., 36(3):811$816,2018$.

SUMMARY: With new digital systems, the role of the microscope as an irreplaceable instrument in the teaching of histology has been called into question. In this study academic performance and student perception for two learning methods were compared: digital and light microscopy, in the muscle tissue unit of the morphology course for first-year undergraduate dentistry at Universidad de los Andes, Santiago, Chile. 92 students were divided into 2 groups: Group 1: light microscopy and Group 2: digital microscope in a web application. All participants observed the same striate muscle, cardiac striated muscle, and smooth muscle samples. An academic performance test was applied (diagnostic and individual structures identify ability). A perception test was conducted after everyone had learned with both systems. For data analysis the $\mathrm{T}$ student test and central tendency with their standard deviation was used. In the cognitive evaluation, the median grades were 5.4 for group 1 and 5.7 for group 2 . In the perception survey, $73.24 \%$ considered the virtual microscope evaluation more fair. It was concluded that the use of virtual microscope tends to have better results than light microscopy. Further investigation is needed to evaluate this new teaching instrument.

KEY WORDS: Medical education; Histology; Visual learning; Virtual Microscopy; Microscopy.

\section{INTRODUCTION}

Histology has been a longstanding basic science course in medical school curricula worldwide. Traditionally, the light microscope has played a major role in student education, and since the 19th century it has been the best tool for teaching and learning histology (Cotter, 2001). But there are a few problems with it, such as: procurement and costly maintenance of microscopes and stained tissues mounted on glass slides, not all sectioned tissues demonstrate all of the structures that should be identified during laboratory study, and finally the pressure to reduce curriculum density and time spent in laboratories (Weaker \& Herbert, 2009).

Today, new technologies are expanding opportunities by casting a wider net in health science learning. Interactive CD-ROMs and the Internet with multimedia have made it possible for personal computers to provide a learning environment similar to that of conventional time-consuming one-on-one tutorial methods (Trelease et al., 2000; Harris et al., 2001; Farah \& Maybury, 2009).

Various digital systems are now available for teaching histology. First, those that incorporate static images, such as slide projections, virtual laboratories on CD-ROM, web pages, and Computer-Assisted Instruction (CAI) where students learn by themselves guided by the program sites (Blake et al., 2003; Lei et al., 2005; Michaels et al., 2005; Bloodgood \& Ogilvie, 2006), but Weaker \& Herbert determinate that there are no significant differences in student performance compared with the light microscope, a situation that did occur when comparing static digital systems with light microscopy. For years, researchers have attempted to compare the effects of medical CAI with traditional media (lectures, laboratory experiences, textbooks), but they are usually difficult to perform properly because variables such as differences in pedagogical 
techniques, differences in informational content, and the novelty factor have commonly not been controlled adequately (Lei et al.).

We compared perception and academic achievement of students that learned muscle histology with the traditional light microscope and static images (Becerra et al., 2015). We concluded that using microscope turn to have better results than slides, but static images were a good tool if it was used as a complement method for light microscopy.

Secondly, the Virtual Microscope (VM), which is an emerging technology that uses software to allow digital images to be viewed as if they were being viewed using a light microscope (Weaker \& Herbert; Krippendorf \& Lough, 2005). The latter technology is not widely used, because the initial investment is too expensive, there is a need to have one laptop per student, and a need to purchase the software (Weaker \& Herbert).

As part of a larger project that integrates the Faculty of Dentistry and Engineering of the Universidad de los Andes, we have jointly developed a virtual microscope software which is capable of doing those functions that we have with light microscopy, and thus optimize costs and improve both the innovation of teaching strategies, and the improvement of academic performance in students, accustomed to the use of digital systems as usual.

The aim of this study was to evaluate the student's academic performance and perception by learning muscle tissue module in the histology unit, using as a study tool light microscopy and a web application created for histological analysis, in first year students of dentistry of the Universidad de los Andes, Santiago, Chile.

\section{MATERIAL AND METHOD}

This is an experimental study that has been approved by the Institutional Review Board of the Odontology Faculty of the Universidad de los Andes. It was conducted in order to compare two learning methods in the muscle tissue module of an histology course. This educational research was analyzed and approved beforehand by the ethics committee of the university.

The study involved 92 students from the first year dentistry class, who attended the histology course. Inclusion criteria considered students enrolled in the 2017 course and the exclusion criteria were students that came from other carriers or repeaters. The sample was random divided into two groups. See the flow diagram of the procedure used (Fig. 1).
Group 1: 46 students used light microscopy as the learning method, in a room arranged to have one microscope per student (Nikon ${ }^{\circledR}$ YS2 Alphaphot-2, Tokyo, Japan) and two teachers. Students were encouraged to explore the histologic sample on their own, to search for the previously determined structures. Working time: 1 hour (Fig. 2)

Group 2: 46 students used a digital microscopy in a room arranged with the same number of computers and two teachers. The micrographs used were obtained from the same histological sample with previously standardized magnification (40X, 100X and 400X). These images were obtained using a photographic camera (Nikon ® Coolpix 5400, 5.4 megapixels, 4X zoom-Nikkor Lens, USA). Working time:1 hour. (Fig. 3)

A protocol was drawn up as a guide for the teachers of both groups, in order to unify the criteria for recognition of structures in the different samples and magnifications used.

At the end of the experimental phase each group took a cognitive test which measured their ability to diagnose the various types of muscle tissue and to identify structures according to the previously proposed objectives, using the following guidelines:

1. Diagnosis of cardiac striated muscle tissue:

a) Intercalated discs, b) Endomysium, c) Muscle fiber.

2. Smooth muscle tissue diagnostic:

a) Muscle fiber, b) Cell nucleus, c) Endomysium

3. Diagnosis of striated skeletal muscle tissue:

a) Muscle fiber, b) Endomysium, c) Perimysium

This evaluation was performed with microphotographs obtained from the samples they looked.

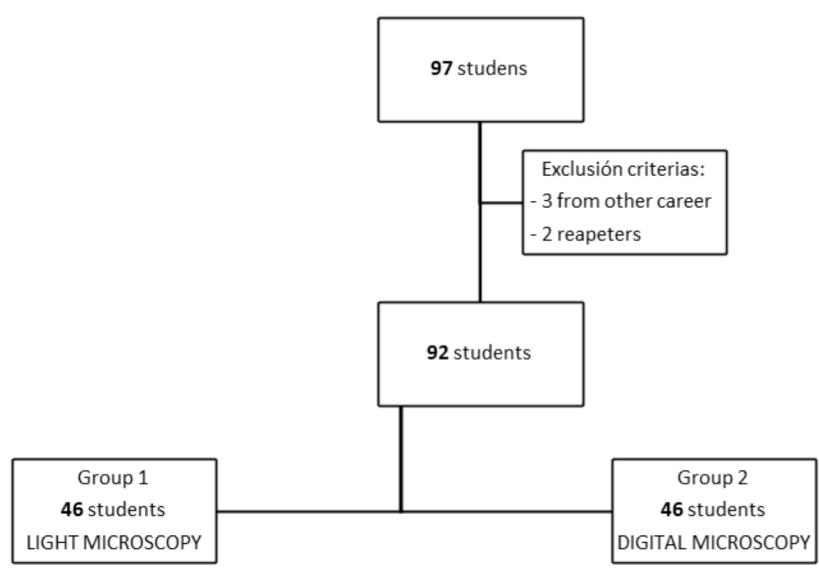

Fig. 1. Flow diagram of the sample enrollment. 

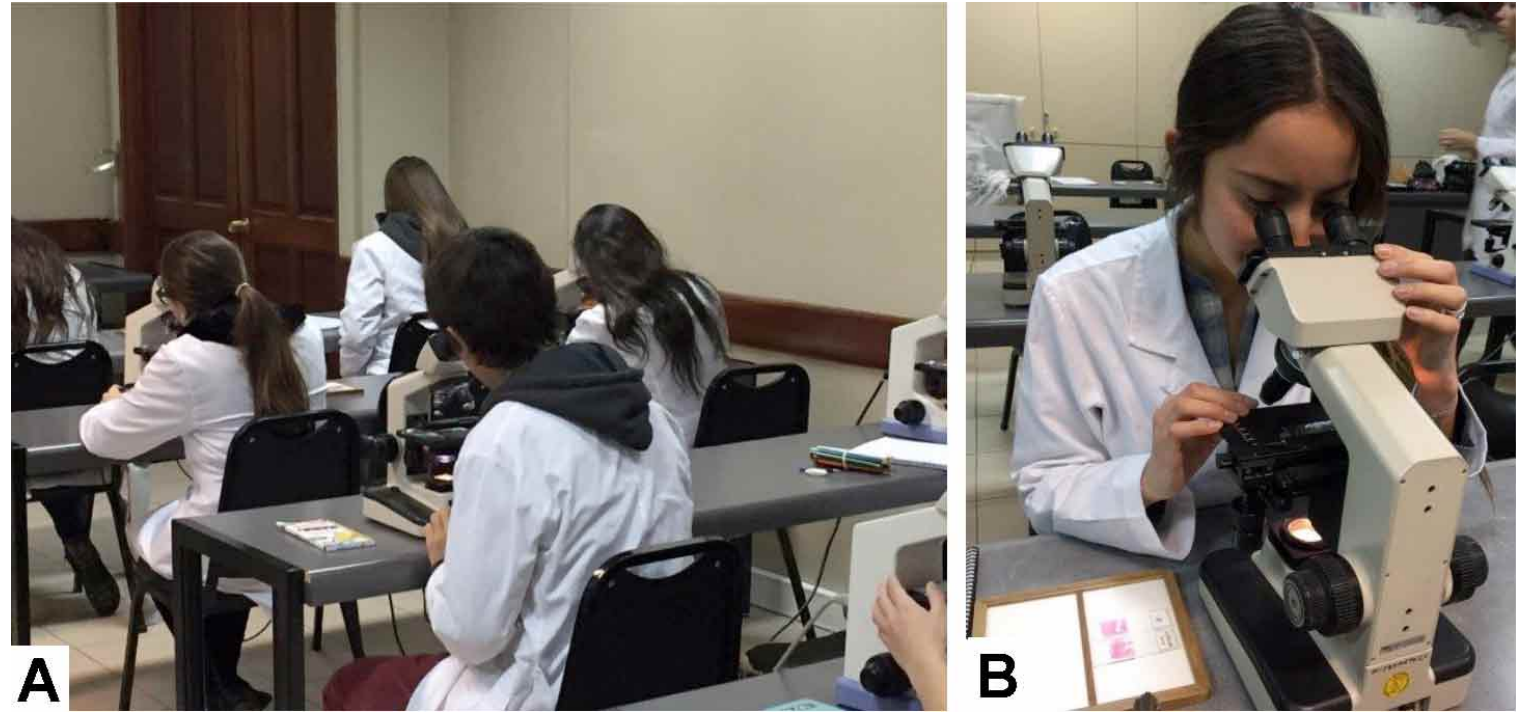

Fig. 2. Light microscopy experience. A) Group 1 performing with the traditional light microscope B) A student learning from light microscopy.
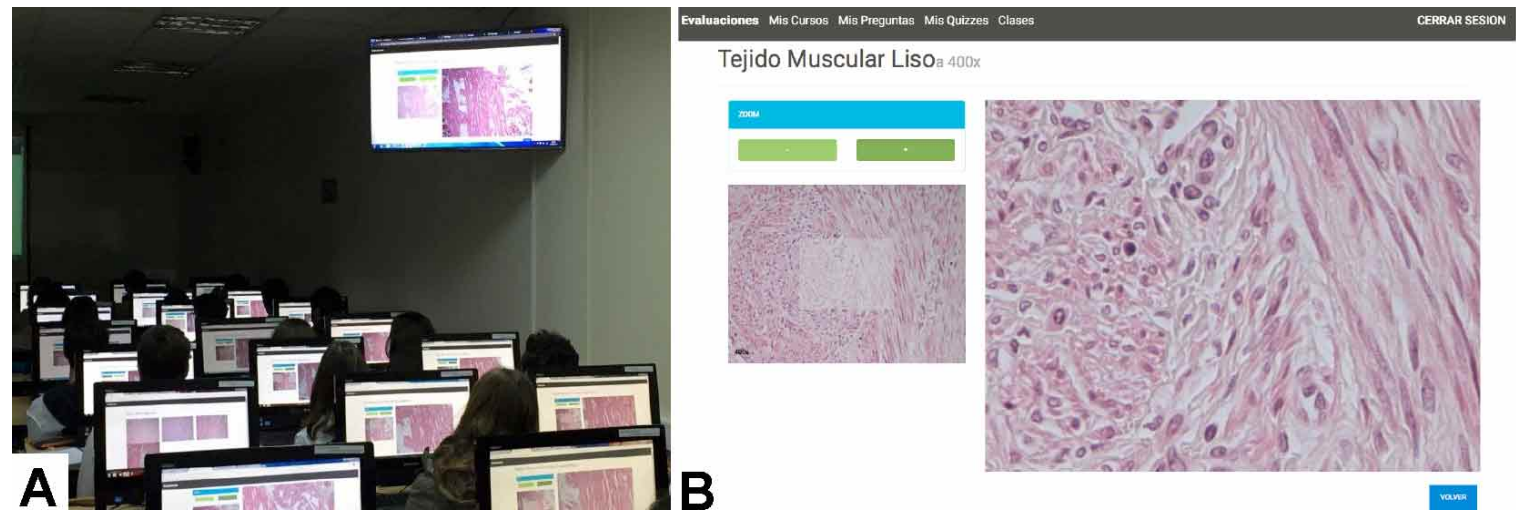

Fig. 3. Digital microscopy experience. A) Group 2 performing with the web application of the microscope software. B) A view of the Web App.

A teacher, who was not involved in the practical activities of the unit, prepared the cognitive test. The guide teachers had no previous access to this evaluation, which was validated by expert histology teachers, assistants, students of the subject, and other teachers of other subjects.

Finally, an anonymous perception survey was applied to both groups in order to determine how the students felt about the learning systems they used. The perception survey was conducted with a Likert scale consisting of 8 questions with 5 options, ranging from strongly disagree (1) to strongly agree (5), a question that ask to the student with which method they feel was more accurate, a comment section which was also validated by other teachers and students, and one question that make them choose what system evaluation they felt fairer. The questions from Likert scale were:
1. Was muscle tissue learning facilitated by using a microscope?

2. Were you able to properly locate the structures using a microscope?

3. Did you feel comfortable using a microscope?

4. Were you motivated by using a microscope?

5. Was muscle tissue learning facilitated by using the digital microscope?

6. Were you able to properly locate the structures using the digital microscope?

7. Did you feel comfortable using the digital microscope?

8 . Were you motivated by using the digital microscope?

Statistical Analysis. The information was analyzed using the SPSS@ $\odot$. The groups were compared with a T Student test with a 95 $\%$ of confident interval. The continuous variables were described with central tendency measures, dispersion, and position. 


\section{RESULTS}

Of a total of 97 students, 5 were excluded (from other careers or repeaters). 92 students participated in the study.

In group 1, 46 students participated, corresponding to those who used optical microscopy as a learning method.

In group 2, 46 students participated, corresponding to those who used digital microscopy as a learning method.

In the cognitive test group 1obtained an average of 5.4 SD 1.04 and group 2 obtained a 5.7 SD 1.1, within a scale of 1 to 7 (with 1 decimal), where 1 is the worst result and 7 corresponds to have all good.

In test $\mathrm{T}$ student the group that use digital microscope obtained a trend of having better results compared to light microscope group $(\mathrm{t}=0.77)$.

The validity of the test was given by the evaluation of the same learning outcomes taught during the experience. The reliability of the cognitive test was expressed with a Chronbach alpha of 0.629 (total of 12 questions).

In the perception test it was observed that the students found that the most accurate method of evaluation was the virtual microscope with $73.4 \%$ of the opinions.

For the different items asked in the survey, which were facilitated learning, if it helped them to locate structures properly, if they felt comfortable, and if they were motivated using the different microscopes. In all items except for motivation, a better perception was appreciated with the virtual microscope, whereas the latter did not show a notable difference in the percentages of positive considerations (Table I).

\section{DISCUSION}

In this experimental study, the academic performance and perception of first year dentistry students in the histology course was evaluated. The light microscopy group was compared with the virtual microscopy group, on the unit of muscle tissue.

The student's distribution in terms of quantity and quality was homogeneous, and thus did not influence the performance and perception results.

In the study published by our team (Becerra et al.), we compared the light microscope with a digital system based on static images. The results at that time, were different than those found in the present study, optical microscope turned out to have better perception (it included the same parameters of motivation, comfort, facility to find structure and easy learning) than the digital system and we were able to appreciate that the best academic results were obtained by those students who studied with light microscopy supported by static images (previously described as the digital system used), which also was supported by Michaels et al.

In this study, academic performance tends $(\mathrm{t}=0.77)$ to improve using the digital system as a teaching method, although from a pedagogical perspective the difference between the averages was important, where light microscope was 5.4 (DS 1.04) and digital microscope was 5.7 (DS 1.1), being this last one consistently better. Some articles (Cotter, 1997; Rosenberg et al., 2006) describe how computed assisted instruction (CAI) could replace microscopes, saying that they are just as effective, considering that this method requires students to study actively. However, in their study Lei et al., concluded that most CAI tools are limited by static images that do not replicate the interactive function of the microscope (Krippendorf \& Lough; Lei et al.).

Krippendorf \& Lough reported in their study that faculty members were surprised that students had learned less with the CAI system, and abandoned this method in order to return to light microscopy. This is consistent with the observation that static images should not be used by themselves, but to support the light microscope (Becerra et al.).

In terms of perception, all the studied parameters showed that digital microscope obtained a higher level of satisfaction than the light microscope, this contrast with our last publication, possibly because now they were able to interact with the software (Becerra et al.), and also digital microscope

Table I. Percentage of agreement and disagreement of the 4 evaluated items in the perception survey.

\begin{tabular}{lcccc}
\hline & \multicolumn{2}{c}{ Agreement } & \multicolumn{2}{c}{ Disagreement } \\
& Light & Virtual & Light & Virtual \\
\hline Easy Learning & $73.24 \%$ & $94.37 \%$ & $1.41 \%$ & $1.41 \%$ \\
Finding structures & $69.01 \%$ & $92.96 \%$ & $12.68 \%$ & $4.23 \%$ \\
Comfort & $73.24 \%$ & $84.51 \%$ & $7.04 \%$ & $7.04 \%$ \\
Motivation & $74.65 \%$ & $73.24 \%$ & $9.86 \%$ & $12.80 \%$ \\
\hline
\end{tabular}


in contrast with static images encourage students to do a personal search of structures, as Lei et al., established in their study where the individual identification of structures by the students appears as the best learning strategy. Other studies also conclude that the interactive methodologies were better perceived than light microscope (Rojas et al., 1999; Rosas et al., 2012).

We also include a question regarding the possible evaluation methods. Today our subject is evaluated asking the student to look and diagnose a specific structure that we show on the light microscope (using a pointer), which has the inconvenience of running the risk of moving from one place. This fact has given to understand that on occasion, these evaluations, could be unfair. Because of that, the new software offers the opportunity to tell our students what they have to identify and indicate a certain structure (in future experiences since in both studies the groups were measured with exactly the same cognitive evaluation), which besides of being recorded, we increase the level of skill for the histological diagnosis of different tissues. That is why we adjudged that $73.4 \%$ of the students found the evaluation with virtual microscopy fairer.

In conclusion the results tend to be better using digital microscope having better academic achievement, better students' perception and better possibilities for evaluation. For future experiences we are making and perfecting the application, where it is worth mentioning that it will be an academic help since it will allow us to carry out quizzes at any time, with automatic answers, allowing the students to obtain immediate feedback and thus allow them to learn from their mistakes. Another important variable to evaluate in next opportunities is its value as a study tool, since being a web application, you can obtain and study the histological preparations at any time and place, giving them the opportunity to study as many times as the students deem necessary. Numerous publications evaluate the factors that positively influence academic performance. Motivational variables are the causal characteristics of having better academic achievement (Weiner, 1985). The effort variable is another important predictor where students that attends classes, participates actively during sessions, adequate time to studying, and delivers assignments of academic work on time, performed significantly better (Velez van Meerbeke \& Roa González, 2005).

\section{ACKNOWLEDGMENTS}

We appreciate the constant support that has given us the Institutional Review Board for educational research of the Faculty of Dentistry, AFODO (from the Spanish: Área de formación docente de la facultad de odontología) and the Odontology Faculty of Universidad de los Andes, Chile.

BECERRA, D.; GROB, M.; ASSADI, J. L.; ASTORGA, C.; TRICIO, J.; MELELLI, R.; SILVA, C. \& SABAG, N. Rendimiento académico y percepción de dos métodos de enseñanza en histología: microscopio de luz y microscopio digital. Estudio piloto. Int. J. Morphol., 36(3):811-816, 2018.

RESUMEN: Los sistemas digitales han puesto en tela de juicio el rol del microscopio óptico como instrumento insustituible para la enseñanza práctica de la histología. El objetivo de este estudio fue comparar el rendimiento académico y la percepción de los alumnos utilizando microscopía óptica y microscopía virtual en base a una aplicación web, utilizada por primera vez. Se dividieron 92 alumnos de primer año de Odontología en 2 grupos: 1: microscopía óptica, 2: microscopía digital. Todos observaron los mismos preparados de músculo estriado esquelético, estriado cardíaco y liso. Al finalizar, rindieron una evaluación formativa para medir conocimientos y luego se invertieron los grupos. Una vez que todos aprendieron con ambos sistemas se aplicó un test de percepción. Para el análisis de datos se utilizó el Test-t de student, medidas de tendencia central y desviación estandar. En la evaluación cognitiva se obtuvo un promedio de 5,4 en el grupo 1 y 5,7 el grupo 2. Respecto a la percepción, un 73,24 \% consideró que la evaluación con microscopia virtual es más justa. La microscopía vitual tiene una mejor percepción por parte de los alumnos y tiende a mejorar el rendimiento académico. Nuevas investigaciones serán necesarias para evaluar esta herramienta de enseñanza.

PALABRAS CLAVE. Histología; Educación en Morfología; Microscopía Virtual.

\section{REFERENCES}

Becerra, G. D.; Grob, L. P. M.; Rodriguez, R. A; Barker, M. M. J.; Consiglieri, L. L.; Ferri, G. G. \& Sabag, S. N. Academic achievement and perception of two teaching methods in histology: Light microscopy and digital systems. Int. J. Morphol., 33(3):811-6, 2015.

Blake, C. A.; Lavoie, H. A. \& Millette, C. F. Teaching medical histology at the University of South Carolina School of Medicine: Transition to virtual slides and virtual microscopes. Anat. Rec. B New Anat., 275(1):196-206, 2003.

Bloodgood, R. A. \& Ogilvie, R. W. Trends in histology laboratory teaching in United States medical schools. Anat. Rec. B New Anat., 289(5):16975, 2006

Cotter, J. R. Computer-assisted instruction for the medical histology course at SUNY at Buffalo. Acad. Med., 72(10 Suppl. 1):S124-6, 1997.

Cotter, J. R. Laboratory instruction in histology at the University at Buffalo: recent replacement of microscope exercises with computer applications. Anat. Rec., 265(5):212-21, 2001.

Farah, C. S. \& Maybury, T. Implementing digital technology to enhance student learning of pathology. Eur. J. Dent. Educ., 13(3):172-8, 2009.

Harris, T.; Leaven, T.; Heidger, P.; Kreiter, C.; Duncan, J. \& Dick, F. Comparison of a virtual microscope laboratory to a regular microscope laboratory for teaching histology. Anat. Rec., 265(1):10-4, 2001. 
BECERRA, D.; GROB, M.; ASSADI, J. L.; ASTORGA, C.; TRICIO, J.; MELELLI, R.; SILVA, C. \& SABAG, N. Academic achievement and perception of two teaching methods in histology: Light and digital microscopy. Pilot study. Int. J. Morphol., 36(3):811-816, 2018.

Krippendorf, B. B. \& Lough, J. Complete and rapid switch from light microscopy to virtual microscopy for teaching medical histology. Anat. Rec. B New Anat., 285(1):19-25, 2005.

Lei, L. W.; Winn, W.; Scott, C. \& Farr, A. Evaluation of computer-assisted instruction in histology: effect of interaction on learning outcome. Anat. Rec. B New Anat., 284(1):28-34, 2005.

Michaels, J. E.; Allred, K.; Bruns, C.; Lim, W.; Lowrie, D. J. Jr. \& Hedgren, W. Virtual laboratory manual for microscopic anatomy. Anat. Rec. B New Anat., 284(1):17-21, 2005.

Rojas, M.; Montiel, E.; Montiel, J.; Ondarza, A. \& Rodríguez, H. Comparative study between traditional teaching methods and computational methods in the human histology. Rev. Chil. Anat., 17(1):81-5, 1999.

Rosas, C.; Rubí, R.; Donoso, M. \& Uribe, S. Dental students' evaluations of an interactive histology software. J. Dent. Educ., 76(11):1491-6, 2012.

Rosenberg, H.; Kermalli, J.; Freeman, E.; Tenenbaum, H.; Locker, D. \& Cohen, H. Effectiveness of an electronic histology tutorial for firstyear dentalstudents and improvement in "normalized" test scores. $J$. Dent. Educ., 70(12):1339-45, 2006

Trelease, R. B.; Nieder, G. L.; Dørup, J. \& Hansen, M. S. Going virtual with quicktime VR: new methods and standardized tools for interactive dynamic visualization of anatomical structures. Anat. Rec., 261(2):6477, 2000

Velez van Meerbeke, A. \& Roa González, C. N. Factores asociados al rendimiento académico en estudiantes de medicina. Educ. Med., 8(2):7482, 2005.

Weaker, F. J. \& Herbert, D. C. Transition of a dental histology course from light to virtual microscopy. J. Dent. Educ., 73(10):1213-21, 2009.

Weiner, B. An attributional theory of achievement motivation and emotion. Psychol. Rev., 92(4):548-73, 1985.
Corresponding author:

Dra. Daniela Becerra G.

Universidad de los Andes Odontology Faculty

Monseñor Álvaro del Portillo 12455

Las Condes

Santiago

CHILE

Email: dani_becerra@hotmail.com

Received: 24-01-2018

Accepted: 29-03-2018 